\title{
Література
}

C. $45-235$.

1. Гербарт И. Ф. Избранные педагогические сочинения / И. Ф. Гербарт - М., 1988. -

2. Дистервег А. Избранные педагогические сочинения / Адольф Дистервег. - М. : Просвещение, 1956. - С. 102-373.

3. Дьюи Д. Психология и педагогика мышления / Джон Дьюи. - СПб., 1914. - С. 43. C. $270-652$.

4. Каптерев П. Ф. Избранные педагогические сочинения. - М. : Педагогика, 1982. -

5. Российская педагогическая энциклопедия: в 2-х т. - М. : БРЭ, 1993. - Т. 1. - 522 с.

6. Педагогическое наследие / Я. А. Коменский, Д. Локк, Ж.-Ж. Руссо, И.Г. Песталоцци. - М. : Педагогика, 1989. - 414 с.

7. Ушинский К. Д. Избранные педагогические сочинения / Константин Дмитриевич Ушинский. - М. : Уч. Пед. Гиз., 1947. - С. 93-142.

\section{ПІДХОДИ ДО ФОРМУВАННЯ ІНТЕЛЕКТУАЛЬНОЇ КУЛЬТУРИ МАЙБУТНЬОГО ВЧИТЕЛЯ ПОЧАТКОВОЇ ЛАНКИ У ПРОЦЕСІ ПРОФЕСІЙНОЇ ПІДГОТОВКИ}

Тамбовська Х. Підходи до формування інтелектуальної культури майбутнього вчителя початкової ланки у прочесі професійної підготовки.

У статті, на основі аналізу підходів до структури й шляхів формування інтелектуальної культури особистості, розглянуто умови, щяо сприяють ефективності даного процесу; показані напрями, які доиільно реалізовувати в ході професійної підготовки майбутнього вчителя початкової ланки освіти, зокрема при формуванні прийомів інтелектуальної діяльності.

Ключові слова: інтелектуальна культура, прийоми інтелектуальної діяльності.

Тамбовская К. Подходы к формированию интеллектуальной культуры будущего учителя начального звена в прочессе профессиональной подготовки.

В статье, на основе анализа подходов структуры и путей формирования интеллектуальной культуры личности, рассматриваются условия, которые оказывают содействие эффективности данного процесса; показаны направления, которые иелесообразно реализовывать в ходе профессиональной подготовки будущего учителя начального звена образования, в частности при формировании приемов интеллектуальной деятельности.

Ключевые слова: интеллектуальная культура, приемы интеллектуальной деятельности.

Tambovska H. Approaches to formation of intellectual culture of the future teacher of an initial link in the course of vocational training.

In article, on the basis of the analysis of approaches of structure and ways of formation of intellectual culture of the person conditions which assist efficiency of the given process are considered; directions which are expedient for realising during vocational training of the future teacher of an initial link of formation, in particular formations of receptions of intellectual activity are shown.

Keywords: intellectual culture, receptions of intellectual activity.

Постановка проблеми. Процес формування інтелектуальної культури особистості довготривалий. Він охоплює весь життєвий період, але найбільш плідним і грунтовним є у шкільному віці. У сучасній психолого-педагогічній науці проблеми формування інтелектуальної культури учнів тісно пов'язані 3 
питаннями інтелектуального розвитку здібностей особистості. Інтелектуальна культура є результатом інтелектуального виховання та розвитку особистості.

Зарубіжні та вітчизняні науковці в галузі педагогіки та психології різнопланово досліджують питання інтелектуального розвитку та інтелектуальної культури учнів різних вікових груп (Д. Брунер, Л. Виготський, Ю. Гільбух, В. Давидов, Б. Ельконін, Л. Занков, 3. Калмикова, Г. Костюк, Н. Менчинська, В. Паламарчук, Ж. Піаже, С. Рубінштейн, Б. Скіннер, Н. Тализіна, Г. Холл).

На наш погляд, інтелектуальна культура є своєрідною характеристикою особистості, яка має широку загальну ерудицію, міцну систему знань у певній галузі науки, гнучкість і оперативність розумових дій, високий рівень творчого мислення, навички пізнавальної активності.

Наукові дослідження психологічних особливостей студентського віку дають підстав вважати період навчання у ВНЗ сприятливим для становлення усіх важливих складових інтелектуальної культури. Період юнацтва характеризується активним духовним становленням особистості, розвитком інтелектуального потенціалу, всіх здібностей, прагненням до самореалізацій і здобуття компетентності в обраній професії.

Аналіз останніх публікацій. Відомі різні стратегії формування інтелектуальної культури майбутнього вчителя. Перша - формування мислення студента через засвоєння змісту знань і системи понять. Сутність цього підходу полягає в припущенні, що процес засвоєння знань є водночас й процесом формування інтелектуальної культури (В. Беспалько, Д. Богоявленська, Н. Менчинська). Друга - цілеспрямоване, поетапне формування інтелектуальних вмінь в умовах оптимізації навчального процесу (В Буряк, А. Паламарчук, В. Паламарчук, О. Савченко,). У будь-якому разі провідними вченими вважається, що інтелектуальна культура є одним із структурних компонентів особистісної й професійно-педагогічної культури (В. Барабанщиков, В. Буряк, В. Гриньова, В. Краєвський, Л. Митина, В. Сласьонін). Науковці А. Алексюк, I. Ладенко, В. Лозова, С. Сковін, М. Чошанов уважають, що інтелектуальна культура студента - це рівень розвитку його особистості в сфері інтелектуальної діяльності. Спираючись на роботи В. Іванової [3], ми розглядаємо структуру інтелектуальної культури як інтегративну єдність змістового, операційного й особистісного компонентів.

Установлено, що в умовах навчання інтелектуальні можливості студентів розвиваються інтенсивніше, ніж за іншими корисними заняттями. Але формування інтелектуальної культури - це процес не стихійний, він потребує від викладачів високого дидактичного мистецтва, вміння навчати так, щоб знання студентів не були поверхневими, не зводились до знайомства тільки 3 окремими положеннями науки, а становили дієву систему, визначаючи життєву позицію, спрямованість особистості, рівень іi педагогічної майстерності.

Актуальність розвитку інтелектуальної культури майбутнього вчителя визначається передусім необхідністю розв'язання таких суперечностей: між потребами в формуванні творчо-інтелектуальних здібностей школярів та 
рівнем готовності учителів до їх формування; між вимогами суспільства до особистості вчителя початкової школи й існуючими стандартами в системі професійної підготовки. Тому, спираючись на існуючі підходи, необхідно синтезувати в інтелектуальній діяльності студента всі компоненти, що сприяють розвитку його інтелектуальних здібностей, ерудиції, мислення, навичок оволодіння знаннями й здатності до розгортання розумово насиченої діяльності учнів у навчальному процесі.

Метою статті $\epsilon$ розгляд найсприятливіших умов становлення в майбутніх вчителів інтелектуальної культури.

Виклад матеріалу. Виходячи з того, що людині властиве активне пізнання оточуючої дійсності, оволодіння інтелектуальним досвідом попередніх поколінь, його систематизація та підйом на цій основі сходинками соціального прогресу.

Розумова діяльність $є$ провідною в житті людини. Вона $є$ найважливішою передумовою соціального становлення особистості, ii морально-духовного забезпечення. Розумове виховання спрямоване на розв'язання ряду завдань:

- опанування системи знань про наукові засади розвитку природи $\mathrm{i}$ суспільства;

- розвиток потенційних інтелектуальних сил особистості;

- формування культури розумової праці.

Для розв'язання цих завдань треба виходити з постулату, що основним багатством окремої людини й людської спільноти взагалі $є$ інтелектуальне багатство. Саме цим критерієм визначається престижність тієї чи іншої держави у світовому товаристві. Тому провідним завдання освіти є створення оптимальних умов для розумового розвитку кожної особистості, максимальне використання потенційних можливостей людини для зростання ії інтелектуальних сил.

Ефективність формування інтелектуальної культури у студентів залежить від таких умов: урахування специфіки навчальних дисциплін; реалізація принципів вищої школи (науковості та швидкого темпу у навчанні, посильності та доступності, самостійності, позитивного емоційного фону та поваги до особистості студента, а також академізму і виховального навчання); високий рівень професійно-педагогічної майстерності викладачів ВНЗ (методичне забезпечення процесу навчально-пізнавальної діяльності студентів та створення сприятливих умов для плідної праці учнівської молоді); якісний і систематичний контроль за навчально-пізнавальною діяльністю. Серед цих умов одне з провідних місць посідає цілеспрямоване формування в студентів прийомів інтелектуальної діяльності (Ю. Бабанський, В. Буряк, Є. Кабанова-Мєллер, Н. Менчинська, П. Підкасистий тощо).

Науковці зазначають, що прийом інтелектуальної діяльності є системою розумових та практичних дій, або операцій, виконуваних для досягнення певної мети. Прийом може бути об'єктивно виражений у переліку дій, який зазвичай представлений логічною схемою, що вказує як здійснюється діяльність для досягнення певної мети. У змісті прийому виокремлюють структурні елементи: мета (результат, на досягнення якого спрямований прийом), склад операцій (послідовність дій, спрямованих на досягнення мети 
прийому), предмет (сукупність об'єктів, на які спрямовано прийом) [1].

За рівнем узагальнення розрізняють прийоми загальні, застосовні в навчальній діяльності 3 різним за змістом матеріалом, і спеціальні, що відбивають специфічний зміст того або іншого навчального предмета [4].

Загальні прийоми відрізняються універсальністю й можливістю переносу в різні сфери діяльності. Більшість педагогів і психологів відносять до них прийоми аналізу i синтезу, сприймання, порівняння, узагальнення, класифікацію, аналітичного спостереження, обробки інформації, роботи 3 навчальним завданням, виконання практичної чи лабораторної роботи тощо [4]. У процесі професійної підготовки студенти засвоюють прийоми, зазвичай, побічно, виконуючи ті чи інші завдання, тому невипадково фахівці скаржаться на те, що студенти погано засвоюють матеріал і в подальшому не вміють застосовувати його у практиці власного викладання. Отже, необхідна спеціальна робота з оволодіння студентами прийомами інтелектуальної діяльності.

3. Калмикова поділяє прийоми на дві великі групи: алгоритмічні прийоми, що є системою жорстко фіксованих приписів, та евристичні прийоми. Перші сприяють формуванню вмінь діяти за зразком, а інші формують якості самостійності в пізнавальній діяльності, дозволяючи знаходити нові способи виконання завдань у нестандартних ситуаціях [5].

Для формування прийомів інтелектуальної діяльності необхідно свідомо знайомити студентів 3 їх складом, пропонувати вправи на відпрацювання прийомів і творче їх застосування на практиці. Наприклад, «Як аналізувати», «Як визначити причинно-наслідкові зв’язки», «Як провести висновки та узагальнення» тощо.

Серед прийомів інтелектуальної діяльності особливе місце посідають прийоми роботи 3 начальною інформацією, 3 текстом. У передовому педагогічному досвіді трапляються приписи щодо правильного тезування, анотування, складання характеристик. Це не є випадковим, оскільки саме неправильно засвоєні прийоми роботи з текстом навчальної книги чи взагалі інформацією гальмують подальший інтелектуальний розвиток студентів. Тоді, коли учні навчилися діяти за зразком, варто пропонувати їм евристичний спосіб організації розумової праці.

С. Поварнін узагальнив різні способи роботи 3 текстом навчальної книги. Серед них:

- переглядове читання (охоплення найбільш істотного у тексті);

- вибіркове (грунтовне читання, але із пропусками);

- повне (без пропусків, але й без особливої роботи над матеріалом);

- читання 3 «проробленням» змісту;

- пасивне читання (слідування думки автора);

- активне читання (оцінювання, аналіз, переробка, побудова узагальнень, висновків);

- поверхневе читання (мінімальна робота над текстом, коли про засвоєння прочитаного мова не йде);

- поглиблене (глибоке продумування змісту) [6, с. 9]. 
Іноді на уроках, особливо в початковій школі, використовують колективне читання 3 наступним коментуванням головної думки, ідеї того або іншого досліджуваного тексту. Цей прийом особливо потрібен тоді, коли трапляється складний для розуміння учнів текст. Звісно, що майбутній вчитель початкової ланки повинен володіти й методикою такого читання.

У передовому педагогічному досвіді пропонуються наступні евристичні прийоми роботи з текстом [3; 6]:

Прийом «Найголовніше». Завдання: прочитати текст (розділ, главу), виразити зміст тексту тільки одним словом, саме головне - однієї фразою.

«Головні іменники». Завдання: прочитати текст (розділ, главу), виразити зміст тексту ключовими іменниками. За ключовими словамиіменниками легко відтворити вихідний текст.

Прийом «Суть». Завдання: протягом певного часу швидко читати текст i олівцем (мишкою, якщо робота здійснюється на комп'ютері) підкреслити сутність інформації. Додаткове завдання: обмінятися результатами роботи з сусідом і порівняти свої досягнення.

«Замітки на полях». Завдання: прочитати текст (на окремому аркуші), зробити замітки на полях у репліках і знаках. Наприклад: «класно!», «чому?», «важливо», «треба запам’ятати!» тощо.

Прийом «Кращий зошит» дозволяє провести аналіз записів і способів виконання завдань.

Прийом «Питання на знання». Завдання: прочитати текст, скласти якнайбільший список питань, які допомагають визначити якість і точність розуміння змісту матеріалу.

Прийом «Термінологічна дуель»: обмін питаннями на визначення поняття, описаного в тексті.

Існує багато інших прийомів інтелектуальної діяльності, яким треба цілеспрямовано вчити студентів і закладати в основу їх інтелектуальної культури.

Висновки. Учитель, який свідомо володіє прийомами інтелектуальної діяльності, спроможний організувати на високому рівні навчально-виховний процес, провести учнів важкими сходинками від незнання до грунтовного знання й розвиненості творчих здібностей. Але становлення цих прийомів неможливе без спеціально організованої роботи, що має стати органічною частиною професійної підготовки майбутнього вчителя.

\section{Література}

1. Буряк В. К. Система дидактичних умов ефективної організації навчальної пізнавальної діяльності / Володимир Костянтинович Буряк // Рідна школа. - 2007. - № 5. - С. 25-27.

2. Гриньова В. М. Формування професійної культури майбутнього вчителя (теоретичний та методичний аспект) / Валентина Миколаївна Гриньова. - Х. : Основа, 1999. - 300 с.

3. Иванова В. П. Активизация творческих способностей как фактор развития интеллектуальной культуры / В. П. Иванова // Мысль и текст : [сб. науч. тр.] - Фрунзе, 1988. - C. 50-63.

4. Кабанова-Меллер Е. Н. Учебная деятельность и развивающее обучение / Евгения Николаевна Кабанова-Меллер. - М. : Знание, 1981. - 96 с.

5. Калмыкова 3. И. Продуктивное мышление как основа обучаемости / Зинаида Ивановна Калмыкова. - М. : Педагогика, 1981. - 350 с.

6. Поварнин С. И. Как читать книги / Сергей Иванович Поварнин. - М. : Книга, 1978. -53 с.

Стаття надійшла до редакції 03.06.2012 p. 